\title{
Association of Exploration Geochemists (AEG)
}

\section{http://www.aeg.org}

Founded in 1970, the Association of Exploration Geochemists is an international organisation specialising in the field of exploration and geochemistry of mineral resources, whose purpose is to:

- Advance the science of geochemistry as it relates to exploration and the environment;

- Further the common interests of exploration geochemists;

- Facilitate the acquisition and distribution of scientific knowledge;

- Promote exchange of information;

- Encourage research and development;

- Advance the status of the profession;

- Sponsor symposia, seminars and technical meetings.

The AEG is composed of about 900 members from about 40 nationalities. Initially funded to promote research in exploration geochemistry, AEG had a strong influence worldwide in the dissemination of exploration geochemistry good practices. A web site of the association provides most of the information related to AEG activities : http://www.aeg.org.

The AEG stands at a junction between a scientific discipline, geochemistry and a significant economic player: the Mineral Industry. AEG is particularly well placed to play a significant role in the field of environmental geochemistry, especially in the evaluation of the mineral industry's environmental impact. This is an area of significant scientific research and service activities in Europe and Northern America, which count a very large number of active AEG members.

To achieve these goals, the Association of Exploration Geochemists published the Journal of Geochemical Exploration from 1972 until 2000. The AEG produced with Elsevier, the Handbook of Exploration Geochemistry, a series of 8 volumes dealing with various aspects of exploration geochemistry: data processing, remote sensing, drainage geochemistry, rock geochemistry, tropical terrains, glacial terrains etc, ...

A new international journal was launched in January 2001, entitled GEOCHEMISTRY: Exploration, Environment, Analysis and coedited with the Geological Society of London. The Journal covers all aspects of the application of geochemistry to the exploration and study of mineral resources, and related fields, including the geochemistry of the environment. Topics include: the description and evaluation of new and improved methods of geochemical exploration: sampling and analytical techniques and methods of interpretation; geochemical distributions in and around mineralized environments; and processes of geochemical dispersion in rocks, soils, vegetation, water and the atmosphere. Papers that seek to integrate geological, geochemical and geophysical methods of exploration are particularly welcome. Given the many links between exploration and environmental geochemistry, the journal encourages the exchange of concepts and data; in particular, to develop mineral resources while protecting the environment. Submission of Letters to the Editor is encouraged. This provides a means of commenting on papers that have been published in this journal.

The Journal will be published by the Geological Society of London (www.geolsoc.org.uk).

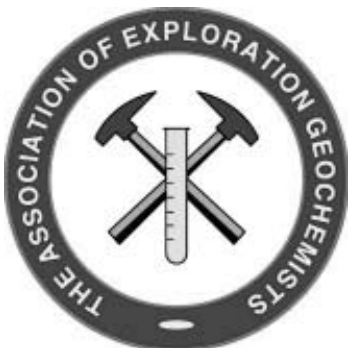

The AEG also publishes a newsletter, entitled EXPLORE which is a professional publication. EXPLORE Newsletter is published quarterly in January, April, July and October. It quotes for :

- speedy publication of recent advances in exploration geochemistry;

- material on multi-disciplinary applications, environmental geochemistry and analytical technology;

- case histories;

- new concepts and modelling improvements;

- descriptions of recently discovered deposits;

- exchange of ideas and 'lively' discussion on wide-ranging topics

- reviews of new software and books;

- geoscience meeting and conference announcements;

- specific ASSOCIATION OF EXPLORATION GEOCHEMISTS issues and directions;

- bibliography of recent geochemically oriented papers;

- advertisements by geochemical labs, consultants, computer and data service groups etc.;

- information on other AEG publications and special book offers.

The AEG holds its biennial International Geochemical Exploration Symposia with associated field trips (e.g. 1999 in Vancouver, Canada; 1997 in Jerusalem, Israel; 1995 in Townsville, Australia; 1993 in Beijing, China; 1991 in Reno, Nevada, USA) The next 21st IGES (International Geochemical Exploration Symposium will be held in Dublin, Ireland by August 29-September 3, 2003 (see more details on www.aeg.org).

For more information on the Association of Exploration Geochemists, contact the business office at:

Association of Exploration Geochemists

Betty Arseneault, Business Manager

P.O. Box 26099

72 Robertson Rd.

Nepean, Ontario

CANADA K2H 9R0

Phone: 6138280199

Fax: 6138289288

E-mail: aeg@synapse.net

Website: http://www.aeg.org

Dr. Philippe Freyssinet

President of AEG

$B R G M$

BP 6009, 45060 Orléans

FRANCE

E-mail:p.freyssinet@brgm.fr

Phone: 33-(0)2.38.64.3005 